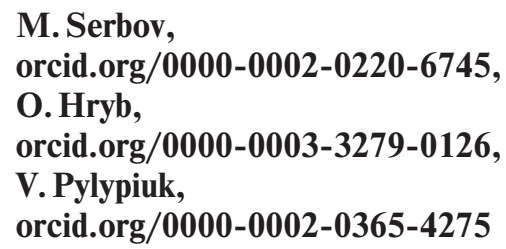

\title{
ASSESSMENT OF THE ECOLOGICAL RISK OF POLLUTION OF SOIL AND BOTTOM SEDIMENTS IN THE UKRAINIAN DANUBE REGION
}

Purpose. The paper deals with assessment of the ecological risks of pollution of soil at the sites where unusable plant protection chemicals are stored, and of the bottom sediments in the Ukrainian section of the Danube and in the Danube region lakes.

Methodology. The applied analytical methods and synthesis of the data obtained while monitoring the studied objects, comparing data, logical generalization and analogies in combination with expert appraisals and monographic and graphical analytic studies.

Findings. It was concluded that the condition of land resources of the Danube region of Ukraine is "unsatisfactory". The risk of the soil ecosystem instability in the majority of the region areas is assessed as "high". The monitoring data pertaining to the sites where unusable plant protection chemicals are stored indicate that the maximum permissible concentrations of certain pollutants surpass the standards by 5.0-32.0 times. The ecological condition of soils is assessed as "medium" - "bad" while the risks are at the level varying between "considerable" to "high". The ecological condition of bottom sediments in the Lower Danube is assessed as "satisfactory", except in Kuhurlui, Yalpuh and Kytai Lakes where it is "unsatisfactory". The ecological risk level in the Ukrainian section of the Danube and in the Danube region ranges from "high" to "considerable".

Originality. For the first time ever, for the Danube region of Ukraine a comprehensive assessment of the ecological risk of soil pollution, which included assessment of the risk of instability of the soil ecosystem resulting from storage of unusable plant protection chemicals, was performed. The integral assessment of the bottom sediment pollution was made for the site located between Reni town and the Danube estuary, and in Danube Lakes. Analysis of the existing methodologies for assessment of the ecological risk of soil and bottom sediment pollution enabled to develop and apply recommendations how to use indicator values describing the ecological condition with due account of the physical degradation and pollution criteria.

Practical value. The obtained results can be used for the development of a strategy of effective and sustainable management of the Ukrainian Danube region's natural resources based upon the instruments and mechanisms aimed at solution of the social and economic development problems bearing in mind possible impact of the destabilizing factors.

Keywords: Ukrainian Danube region, ecological risk, condition, pollution, soils, bottom sediments

Introduction. System and highly negative anthropogenic processes that have been taking place during last decades as well as erroneous belief in non-depletability and boundless ability of ecosystems to self-cleaning have led to considerable violations in the development of economic and ecological systems. That is why the scientists recognized a necessity to ensure the life and activities of population in the regions of Ukraine subject to accounting of the consequences of economic activity when assessing the possibilities of our future generations to meet their needs only [1].

Current use of the country's soil resources demands a rapid implementation of the rational nature management the first and most important stage of which is making a comprehensive assessment of the quality condition of soils and determination of the permissible anthropogenic impact [2]. Nowadays in Ukraine there is just a standard which determines a permissible level of soil pollution with harmful substances [3]. It means that determined are the maximum allowable concentrations (MAC) of harmful substances in the surface layer of soil only which should not (either directly or indirectly) produce a negative impact on human health and on the soil's capacity for self-cleaning. These standards have been developed for the substances that can migrate in the atmosphere and groundwater and negatively influence the agricultural product quality. However, there exists a necessity to scientifically substantiate and set up the individual MACs for soils and bottom sediments of various qualities and types with due account of the peculiarities of migration and transformation of the harmful substances.

Literature review. A number of scientists have studied scientific and methodological basics of the economic and ecological assessment of interaction between society and environ-

(C) Serbov M., Hryb O., Pylypiuk V., 2021 ment, including such studies for the territory of Ukraine $[1,4$, 5]. Special attention of such studies was given to the analysis and assessment of soil and water resources being the basic natural factors that determine both the production level of the regions and the social component of livelihood [6]. Considerable attention was also given to theoretical and methodological principles of the resource and ecological safety optimization.

The water and land potential of each region makes the basis of its economic development and social and economic welfare. Along with that, the level of utilization and economic loading in the prevailing part of the Ukrainian territory have already reached such levels that exceed the ability to self-regenerate.

Among the main directions for solving the indicated problems studied by national and foreign scientists, it is possible to single out the following:

- development of the conceptual foundations of the economic and ecological assessment of the natural resource potential from the viewpoint of the safe and sustainable development [1, 4];

- determination of the ecological safety indicators that characterize the level of protection against the negative impact with reference to achievement of the social and ecological system targets [6];

- theory of the region-based safe and sustainable development [7, 8];

- probability of causes and consequences of the events and levels of losses in the ecological risk assessment theory [9].

Still, it was noted that some foreign scientists [10] consider that the wide practical application of diverse statistical analysis methods to assess ecological risks are not always acceptable. It concerns, first of all, the assessment of the risks of technological origin, particularly when implementing new technologies. In this instance it is proposed to use the probabilistic analysis 
of safety which is based on modeling threats and use of the scenario approach [11].

A group of national scientists $[5,8]$ studied possibilities of emergence of ecological risks on the assumption of accidentfree situations and no damage inflicted on the ecosystem. Such studies occupy a special place in modern economic and ecological management as these situations are connected with delayed hazard.

Assessment of the risk of a single or small number of agents of impact on the limited number of the objects of impact presents the main drawback of the conventional approach as the work [12] states. The paper [13] proposes the approach to assessment of the region-scale ecological risk applicable to large areas comprising numerous objects of impact. The difference of such approach is in construction of the generalized map of the region taking into account characteristics of the biological resources and interests of the region development by the use of various technogenic systems followed by identification of the homogenous zones and construction of the conceptual model. The work [4] investigated the conceptual and categorical definitions of the ecological safety and ecological risk. It is indicated that among the numerous causes of ecological hazards the essential one is due to inconsistency of the scientific theoretical base to the practical tasks. Along with the economic and financial aspects, the foreign scientists [14, 15] put forward solutions of the institutional issues and problems of the ecological policy of various levels. The alternative brought forward in the work [16] and aimed at solving this task proposes to pay the main attention to the environmental activity in water basins, development of modern, low-waste and resource-saving technologies. A special role of investments in the environmental activity in water basins is emphasized in the work [5] as well.

Unsolved aspects of the problem. It should be noted that despite a considerable volume of publications dealing with the study on ecological risk assessment, there remain issues necessitating a scientific search of the modern integrated approaches to ensure regional resource and ecological safety. Besides, assessment of the ecological risks is considerably limited by the lack of data illustrating the impact on the objects of risk as regards assessment of the consequences. This consideration intensifies the need to ensure a system approach to collection of such data and modeling the safety assessment of the regional ecological systems. Such approach is of the utmost significance as the main goal of the risk assessment lies in communicating the complicated and specific scientific information to persons who should make effective managerial decisions.
Topicality of the assessment of the risk of soil and bottom sediment pollution in water basins of the Ukrainian Danube region is linked to the following issues:

- the unique nature of the Danube region within the boundaries of Odesa region of Ukraine from the viewpoint of its geography, environment and economic development prospects for the movement to integration in Europe (Fig. 1);

- the necessity to assess the ecological risks because of the more stringent requirements of the environmental legislation and as a preventive measure against possible considerable economic losses in future;

- lack of the study on possible ecological risk scenarios for the region under conditions of the ever increasing anthropogenic impact upon the natural ecosystems;

- absence of the developed integrated strategy of effective and sustainable management of natural resources based on assessment of the regional risks which is aimed at solving the problems arising between the social and economic development goals and the negative consequences of the destabilizing factors impact.

Purpose. The work was aimed at assessment of the ecological risks of soil pollution at the sites where unusable plant protection chemicals are stored, and bottom sediments pollution within the boundaries of the Ukrainian section of the Danube and in Danube Lakes. These problems necessitated to solve the following tasks:

1. To analyze the methods for assessing the ecological risks of soil and bottom sediment pollution.

2. To develop recommendations pertaining to the use of indicators of soil condition with due account of the physical degradation and pollution of soil.

3 . To assess the general condition of the land resources in the Danube region of Ukraine and assess the risk of instability of the soil ecosystems.

4. To assess the ecological risks associated with handling unusable plant protection chemicals.

5. To assess the condition and ecological risks of bottom sediment pollution in the water basins of the Danube region of Ukraine.

Methods. In order to solve the set tasks described in the paper on the basis of the field ecological monitoring of the territory the authors of the work [2, 17], who directly participated in the monitoring, made use of the analytical methods and consolidation of the obtained results, comparative studies, logical generalization and analogies in combination with expert appraisals and monographic and graphical analytic studies. In compliance with the effective DSTU 2156-93, "an ecological risk means a probability of the negative conse-

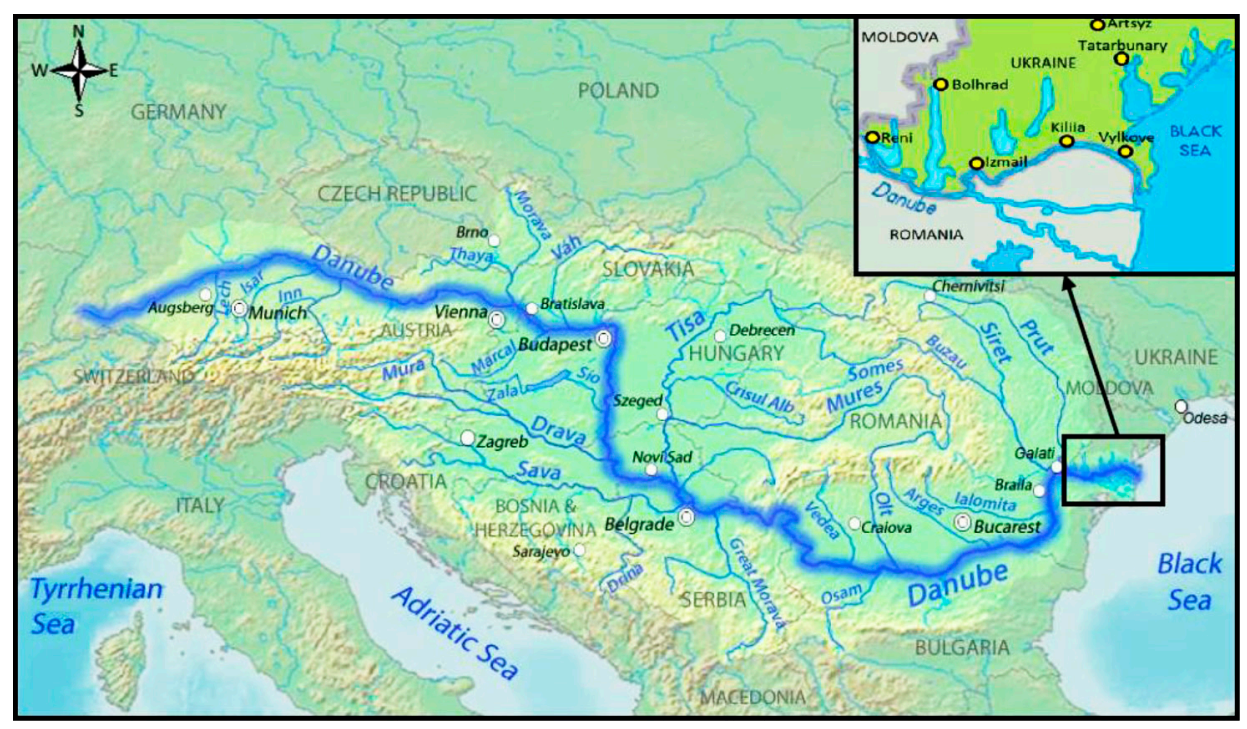

Fig. 1. Map chart of the Danube basin and the site of the Ukrainian Danube region 
quences resulting from a totality of harmful impacts on the environment which produce irreversible degradation of ecosystems". Taking into account this definition, the integrated assessment of the ecological condition of soil and bottom sediments in the Danube region of Ukraine and the determination of the risk of their pollution were accomplished with the use of methods proposed in the works $[18,19]$. The above mentioned methods were adapted to the conditions of our country and made it possible to determine the allowable anthropogenic load so as to preserve the balance of the ecosystem and its main components. Besides, the obtained results allow of making specific managerial decisions pertaining to mitigation of the negative impact upon the environment and choosing priorities of the environment protection measures to be implemented.

When performing assessment of the soil pollution risks in the Danube region of Ukraine, the following considerations were taken into account:

1) the current condition of the agricultural lands, including determination of their structure and top soil, ecologic resistance of the lands, content of humus and the main elements of plant nutrition, productivity of the staple crops, the existing erosion and salting level as well as scoring (degree of quality) of lands;

2) condition of the wooded lands indicating their structure, forest coverage with relation to land areas, forest quality, forest stand, stock of forest forming species and the average wood increment;

3 ) current state of the nature reserve lands (NRL) indicating the NRL structure, number and locations of the existing NRL objects according to the territorial taxons and percentage of the NRL in the land structure of the corresponding taxon.

The integral indicators of the land condition $\left(I_{z_{s} s t}\right)$ were determined as the average score of all indicators

$$
I_{z \_s t}=\frac{1}{k} \sum_{i=1}^{k} Z_{i},
$$

where $Z_{i}$ is the score of the $i^{\text {th }}$ indicator; $k$ is the number of indicators.

Depending on the obtained results, each indicator was assigned the appropriate score $\left(I_{i}\right): 1$ - good condition; 2 - satisfactory; 3 - medium, 4 - bad; 5 - very bad.

The integral indicator of the land pollution $\left(I_{z a b}\right)$ was calculated by the formula

$$
I_{z a b}=\max \left(I_{1}, I_{2}, \frac{1}{4} \sum_{i=3}^{6} I_{i}, I_{7}, \frac{1}{3} \sum_{i=8}^{10} I_{i}\right),
$$

where $I_{i}$ is score of the $i^{\text {th }}$ indicator

Soil resistance to pollution depends on a great number of factors, the main being: slope steepness, stoniness, specific resistance, structure, mechanical composition of soil, water conditions, humus content and others. Depending on the value of the factor of the territory, the indicator score of the territorial taxon was determined. At the concluding stage the integrated evaluation of the ecological resistance of soil $(C, \%)$ was determined by the formula shown below

$$
C=\frac{100}{Q} \sum_{j=1}^{N} C_{j},
$$

where $C_{j}$ is the score of the $j^{\text {th }}$ assessment indicator; $N$ is the number of indicators in the calculation pattern used for assessment; $Q$ is the maximum possible sum of scores of the indicators used for making the calculation $(Q=4 N)$ in accordance with the used indicators.

As the indicator value characterizing circulation of the industrial waste and its accumulation, the reduced density indicator of the industrial waste formation for a year $\left(Z_{W}, \mathrm{t} / \mathrm{km}^{2}\right)$ was proposed which was calculated by the formula

$$
Z_{W}=\frac{I_{z u v}}{S},
$$

where $I_{z u v}$ is the integrated indicator of the total waste formation (accumulation), t/year; $S$ is the area of the appropriate territorial taxon, $\mathrm{km}^{2}$.

In its turn, $I_{z u v}$ was determined by the formula

$$
I_{z u v}=5000 M_{1}+500 M_{2}+50 M_{3}+M_{4},
$$

where $M_{1}, M_{2}, M_{3}$ and $M_{4}$ are the number of the formed (accumulated) industrial wastes classified according to the $1^{\text {st }}$, $2^{\text {nd }}, 3^{\text {rd }}$ and $4^{\text {th }}$ hazard category, $\mathrm{t} /$ year.

The indicators of the ecological condition of soils are: the land areas withdrawn from the agricultural use because of their degradation, coverage of the humus layer with abiotic depositions, increase in soil density, high groundwater level and loss of humus for the last decade. Also, the following factors were accounted for: increase in the highly soluble salts and a fraction of the exchangeable sodium in soil, decrease in the active microbial mass level, excessive values of the MAC of chemicals, a part of the polluted agricultural products and decrease in the average productivity of the agriculture [2].

The integrated index of the ecological condition of soils $\left(I_{G r_{s} t}\right)$ was determined as the maximum score of the worst indicator

$$
I_{G r_{-} s t}=\max \left(I_{1}, I_{2}, \ldots, I_{j}, I_{k}\right),
$$

where $I_{j}$ is the score of the $j^{\text {th }}$ indicator; $k$ is the number of indicators.

On the basis of the accepted approach for the integrated assessment of the land condition, the regional assessment of the ecological risk at the current condition of the $i^{\text {th }}$ component of the environment was calculated by the formula [18]

$$
P_{i}^{c}=f_{i}\left(K_{i}^{c}, H_{i}^{c}\right),
$$

where $P_{i}^{c}$ - probability of the soil resistance deterioration under the current condition of the $i^{\text {th }}$ components of the ecosystem; $K_{i}^{c}$ - current condition of the $i^{\text {th }}$ component of the environment; $H_{i}^{c}$ - anthropogenic load value resulting from the impact of negative factors on the $i^{\text {th }}$ component of the environment.

The ecological risk for soils $\left(P_{s}^{c}\right)$ was determined by the formula

$$
P_{s}^{c}=f\left(S_{d}\left\langle d=\overline{1, N_{S}}\right\rangle, H_{S I}\left\langle l=\overline{1, N_{H S}}\right\rangle\right),
$$

where $S_{d}$ is the current condition of soils; $H_{S I}$ is the integrated assessment of the anthropogenic load resulting by the impact of the negative factors on soils according to the $d^{\text {th }}$ indicator.

The critical condition value $\left(K_{i}^{k}\right)$ of the $i^{\text {th }}$ component of the environment, when degradation starts and the resistance of the ecosystem is disturbed, occurs in accordance with the following two scenarios. First, when the current condition of the ecosystem is close to the critical one, then even a small anthropogenic load $\left(H_{i}\right)$ can lead to the intensive development of the degradation processes. Second, when the anthropogenic load exceeds the permissible scales.

In order to make a more detailed assessment of the ecological risk, it is required to consider the regional ecosystem ability to self-regeneration, distance of the ecosystems from the sources of impact, duration of the impact produced by the anthropogenic load, and so on. Then the risk of disturbance of the $i^{t h}$ component of the ecosystem resistance $\left(P_{i}\right)$ is expressed as a function of the kind

$$
P_{i}=f\left(r, K_{i}^{K}, H_{i}, L, t\right),
$$

where $K_{i}^{K}$ is the critical condition of the $i^{\text {th }}$ component of the ecosystem; $r$ is the distance of the ecosystems from the sources of impact; $t$ is time required for the ecosystem to reach the 
critical condition; $L$ is ability of the ecosystem to self-regenerate after the negative impact of the anthropogenic load $H_{i}$.

Results. Use of the agricultural lands and ploughness of the Danube areas of Odesa region (Tatarbunar, Artsiz, Reni, Izmail and Kiliia districts) are characterized, on the average, by such indicators: $66.2 \%$ - the level of the agricultural land use; $87.0 \%-$ ploughness of the territories [2]. It was established that the integral index of the land condition $I_{z s t}$ in the Danube areas of Odesa region (Table 1) varies from 3.00 to 3.17 and corresponds to the $2^{\text {nd }}$ group of the sites $\left(3.0<I_{z s t}<3.3\right)$ where the soil condition is assessed as "unsatisfactory". From the ecological viewpoint, the lands of the Danube region of Ukraine should be considered as re-cultivated agricultural landscapes used for many centuries. The current condition of the land use does not meet the sustainable nature management requirements, first because of violation of the ratio between the ploughed land area and the natural forage land areas, which negatively impacts the agricultural landscape resistance. The agricultural use of the lands exceeds the ecologically permissible standard and has been but increasing over last years. The main problem caused by degradation of the land condition in the Ukrainian Danube areas, same as in Odesa region, is, basically, the degradation of soils, primarily, due to the erosion process development and physical degradation of soils.

According to the expert assessment, the physical degradation of soils is manifested, above all, in excessive density almost across $38.4 \%$ of the ploughed area of the region while the total area of the degraded soil reaches 98,000 ha. Being a factor characterizing degradation of the ground layer and ecological hazard, erosion is assessed, above all, by intensity of soil wash and the volumes of the ground substrate transfer, which varies from $10-15$ to $20-25 \mathrm{t} / \mathrm{ha}$. One of the reasons of degradation of the ecological condition of lands in the region is flooding and landslides which have activated in the recent years. Altogether for the region, the total flooded areas reached 20.6 thousand ha in 2014-2016, and the total scale of flooding reaches almost $62 \%$ of the territory [2].

Evaluations of the soil ecosystem resistance disturbance in Artsiz, Kiliia and Tatarbunar districts have shown the "minimum" level $\left(P_{s}^{c}=0.20\right)$, and for Izmail and Reni districts "high" level $\left(P_{s}^{c}=0.25\right)$.

As regards assessment of the ecological risks when handling unusable plant protection chemicals (UPPC), it was determined that in the territory of the Danube regions there are 6 warehouses containing UPPC or $1.08 \%$ of the total number of such warehouses in Odesa region. The volume of stored UPPC therein amounts to $27.8 \mathrm{t}$ or $2.1 \%$ of their total volume in the regional warehouses [17]. These warehouses have no certificates and their condition is unsatisfactory.
Assessment of soil pollution was accomplished by comparing the measured concentrations of pollutants (cadmium, copper, zinc, manganese, cobalt, arsenic, lead, mercury, DDT, DDE, DDD, $\gamma$-HCCH/lindane, geptachlorine) with the MACs established in Ukraine [3] and with sanitary standards [20].

Assessment of soil pollution was performed with the use of the data obtained from 645 tests. The results of the performed studies made it possible to record excessive MACs of such pollutants:

- copper in 1 sample $(2.3 \%$ of the total number of samples, 1.67 of MAC);

- lead in 2 samples ( $4.6 \%$ of the total number of samples, $1.05-1.20$ of MAC);

- zinc in 4 samples $(9.3 \%$ of the total number of samples, $1.04-1.26$ of MAC)

- DDT in 5 samples (11.6\% of the total number of samples, $1.50-39.0$ of MAC);

- DDE in 4 samples $(9.3 \%$ of the total number of samples, $1.01-22.0$ of MAC);

- DDD in 1 sample (2.3\% of the total number of samples, 5.00 of MAC).

The most hazardous situation is observed near the following UPPC warehouses:

- in Shevchenkove village of Kiliia district where all soil samples contained excessive MAC of zinc (by 1.05-1.26 times), and one sample tested for lead content has shown above-limit 1.20 times, DDT and DDE were exceeded 1.80-2.20 times;

- in Zadunaivka village of Artsiz district where $50 \%$ of samples exceeded the MACs for DDT (2.10-32.0 times), for DDE (1.01-22.0) times and for DDD (5.00 times).

Assessment of the ecological condition and calculations of the ecological risk levels for soils at the UPPC warehouse locations have proved the following:

1) the ecological condition of soil near Desantne village and Stari Troiany village of Kiliia district, and Utkonosivka village and Novokalanchak village of Izmail district is determined as "satisfactory", and the ecological risk level as "high" $\left(P_{s}^{c}=0.25-0.30\right)$;

2) the ecological condition of soil near village Novoselivka and village Vasylivka of Kiliia district, and Kirnychki village of Izmail district, Ostrovne village, Hlavani village Kamianske village and the area between villages Dilen and Novoselivka of Artsiz district is determined as "medium", and the ecological risk level as "considerable" $\left(P_{s}^{c}=0.35-0.40\right)$;

$3)$ the ecological condition of soil near Shevchenkove village of Kiliia district and Zadunaivka village of Artsiz district was determined as "bad", and the ecological risk level as "high" $\left(P_{s}^{c}=0.60-0.65\right)$.

Assessment of the land condition in the Danube areas of Odesa region

\begin{tabular}{|c|c|c|c|c|c|c|c|c|}
\hline \multirow[b]{2}{*}{ Administrative-territorial entity } & \multicolumn{6}{|c|}{ Ecological condition indicators } & \multirow{2}{*}{ 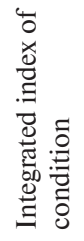 } & \multirow{2}{*}{ 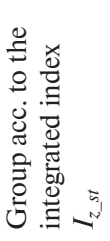 } \\
\hline & ploughness & $\begin{array}{l}\text { humus } \\
\text { content }\end{array}$ & $\begin{array}{l}\text { ecological } \\
\text { resistance }\end{array}$ & $\begin{array}{l}\text { forest } \\
\text { cover }\end{array}$ & $\begin{array}{l}\text { erosional } \\
\text { feature }\end{array}$ & reserves & & \\
\hline Artsiz district & 3 & 3 & 3 & 2 & 4 & 4 & 3.17 & II \\
\hline Kiliia district & 4 & 3 & 3 & 2 & 4 & 2 & 3.00 & II \\
\hline Izmail district & 4 & 3 & 2 & 2 & 4 & 4 & 3.00 & II \\
\hline Reni district & 3 & 3 & 3 & 2 & 4 & 4 & 3.17 & II \\
\hline Tatarbunar district & 4 & 3 & 3 & 2 & 4 & 2 & 3.00 & II \\
\hline Danube districts in whole & 4 & 3 & 3 & 2 & 4 & 3 & 3.17 & II \\
\hline Odesa region in whole & 3 & 3 & 2 & 3 & 4 & 4 & 3.17 & II \\
\hline
\end{tabular}


Assessment of the ecological risk of the bottom sediment pollution in the water basins of the Ukrainian Danube region was accomplished at the site located between Reni town and the estuary part of the Danube as well as in Danube Lakes. Assessment of the bottom sediments pollution was made on the basis of samples taken from 27 monitored locations [2]. The list of pollutants is similar to that one used for assessing soil pollution. Assessment of the bottom sediment pollution was accomplished on the basis of 390 tests. The results of the performed studies (Table 2) have proved that the MACs were exceeded as regards such pollutants:

- copper in 13 samples (3.3\% of all samples, moreover, in 12 cases (making $9.2 \%$ of all samples) - the MACs were exceeded in various sites of the Danube and in 1 case only $(0.8 \%$ of all samples) - in Yalpuh Lake at the site of the Bolgrad water intake the MACs were exceeded 1.07-2.70 times);

- zinc in two samples taken in Yalpuh Lake $(1.5 \%$ of all samples) - confirmed that the MACs were exceeded 1.551.57 times;

- manganese in 4 samples taken at the site of the Danube (3.1\% of all samples) the MACs were exceeded 1.15-1.70 times;

- lead in 3 cases ( $2.3 \%$ of all samples) the MACs were exceeded $1.65-4.95$ times;
- nickel in 4 cases ( $3.1 \%$ of all samples) the MACs were exceeded $1.25-1.40$ times).

In the bottom sediments of the Danube (between Reni town and the estuary section of the river) and in Danube Lakes the residual quantity of the plant protection chemicals (DDT, DDE, DDD and $\gamma-\mathrm{HCCH} /$ lindane, geptachlorine) in the tested samples was not established.

The spatial analysis of the bottom sediment pollution indicators in the Ukrainian section of the Danube indicates that the maximum pollution is observed at the trans-border site near Reni town where the MAC of lead was determined as excessive (1.70-4.95 times) and that one of copper (2.302.70 times)

At the river site near Izmail town the bottom sediment quality indicators meet, on the whole, the established MACs, however, pollution of the bottom soil with copper equals 1.251.50 of the MAC.

At the river site near Kiliia town the quality indicators of bottom sediments were again observed: copper - to 2.70 of $\mathrm{MAC}$, manganese - to 1.60 of MAC and nickel - to 1.35 of MAC.

At the Danube section, $500 \mathrm{~m}$ upstream and $500 \mathrm{~m}$ downstream of Vylkove town the bottom sediment pollution is in-

Table 2

Results of the expert assessment of the ecological condition of bottom sediments and ecological risks within the boundaries of the Ukrainian section of the Danube and in the Danube region lakes

\begin{tabular}{|c|c|c|c|c|c|c|c|c|}
\hline \multirow[b]{2}{*}{ Water basin site } & \multirow{2}{*}{ 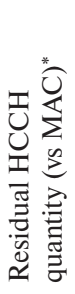 } & \multirow{2}{*}{ 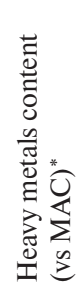 } & \multicolumn{3}{|c|}{$\begin{array}{c}\text { Excess of MAC by pollutants of various } \\
\text { hazard categories* }\end{array}$} & \multirow{2}{*}{ 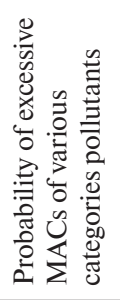 } & \multirow{2}{*}{ 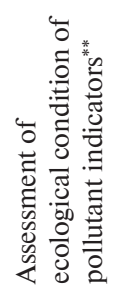 } & \multirow[b]{2}{*}{$\begin{array}{l}\text { Ecologic } \\
\text { risk level }{ }^{* * *}\end{array}$} \\
\hline & & & $\begin{array}{l}I^{s t} \text { hazard } \\
\text { category }\end{array}$ & $\begin{array}{l}2^{\text {nd }} \text { hazard } \\
\text { category }\end{array}$ & $\begin{array}{l}3^{r d} \text { hazard } \\
\text { category }\end{array}$ & & & \\
\hline Danube - Reni town & II & IV & IV & III & II & 0.30 & B & considerable \\
\hline Danube - Izmail town & II & III & II & II & II & 0.20 & A & high \\
\hline Danube - Kiliia town & II & IV & III & III & II & 0.40 & B & considerable \\
\hline Danube - Vylkove town & II & IV & III & III & II & 0.40 & $\mathrm{~B}$ & considerable \\
\hline Danube - Ochakiv estuary & II & III & II & II & II & 0.20 & A & high \\
\hline Danube - Bystryi estuary & II & III & II & II & II & 0.20 & A & high \\
\hline Starostambulske estuary & II & III & II & II & II & 0.20 & A & high \\
\hline Kahul Lake - vil. Nagirne & II & III & I & II & II & 0.20 & A & high \\
\hline Turka Lake - vil. Orlovka & II & III & I & II & II & 0.20 & A & high \\
\hline Katral Lake - vil. Orlovka & II & III & I & II & II & 0.20 & A & high \\
\hline Kuhurlui Lake - branch & II & III & III & II & II & 0.30 & B & considerable \\
\hline $\begin{array}{l}\text { Yalpuh Lake - vil. Kotlovyna (potable water } \\
\text { intake) }\end{array}$ & II & III & III & III & II & 0.40 & B & considerable \\
\hline Katlabukh Lake - v. Suvorove & II & III & $\mathrm{I}$ & II & II & 0.30 & A & considerable \\
\hline Lunh Lake - vil. Bohate & II & III & I & II & II & 0.20 & A & high \\
\hline Safian Lake - vil. Safiany & II & III & I & II & II & 0.20 & A & high \\
\hline Kitai Lake - vil. Stari Troiany & II & III & II & II & II & 0.30 & $\mathrm{~B}$ & considerable \\
\hline Velykyi Solonyi liman - nearby vil. Desantne & II & III & I & II & II & 0.20 & A & high \\
\hline Sasyk (Kunduk) liman - near vil. Borysivka & II & III & II & II & II & 0.30 & A & considerable \\
\hline
\end{tabular}

Remarks:

* ecological condition of the bottom sediments versus to the appropriate MACs and residual quantities of the plant protection chemicals (HCCH) meet: I - "safe"; II - "satisfactory"; III - "medium"; IV - "bad"; V - "very bad";

** ecological condition of pollution indicators is defined as: "satisfactory" if the indicator $I_{z-s t}<3.0$ (A); "unsatisfactory" if the indicator $3.0<$ $<I_{z \_s t}<3.3$ (B); "bad" if the indicator $I_{z \_s t}>3.4(\mathrm{C})$;

*** the ecological risk level is defined as "minimum" - at $P_{s}^{c}<0.20$ probability; "high" - at $P_{s}^{c}=0.21-0.37$ probability; "considerable" - at $P_{s}^{c}=0.38-0.63$ probability; "very high" - at $P_{s}^{c}=0.64-0.80$ probability; and "catastrophic" - at $P_{s}^{c}>0.80$ probability 
creasing: copper - to 3.05 of MAC, manganese - to 1.70 of MAC and nickel - to 1.40 of MAC.

In the Danube delta at the sites of Ochakiv estuary, Bystryi estuary and Starostambulskyi arm the MACs in the bottom sediments are exceeded as regards copper only (1.15-2.00 times).

The conducted analysis of the bottom sediment pollution variability in Danube Lakes has shown that, on the whole, they meet the established requirements as regards soil quality. Excesses of the MACs were determined in 4 samples only (3.0\% of all samples) taken in Kuhurlui and Yalpuh Lakes according to three pollutants: lead (1.77 of MAC), zinc (1.55 of MAC) and copper (2.6 of MAC). At that, pollution of the bottom sediments with lead in Kuhurlui Lake was recorded in the immediate vicinity of the branch that connected the lake with the Danube, therefore, such pollution can be explained by its coming together with river water and with the deposits accumulated in the bottom soil of the lake near the connecting branch. The monitored data concerning pollution of the bottom sediments in the Ukrainian section of the Danube and in Danube Lakes are sporadic, therefore, it cannot be fully characteristic of the spatial and temporal variability of the bottom sediment pollution [2]. The indicated above makes it practically impossible to use statistical models to evaluate the risk of pollution of these water basins. The available data enabled, actually, to conduct a preliminary expert assessment of the ecological risks only.

Assessment of the bottom sediments pollution testifies "satisfactory" condition of the bottom soil at the sites near Izmail town, in the beds of Ochakiv estuary, Bystryi arm and Starostambulskyi estuary. In the river sites within Reni, Kiliia and Vylkovo towns the ecological condition of the bottom soil is assessed as "unsatisfactory".

The ecologic risk level for the entire Ukrainian section of the Danube is appraised by experts in the range of "high" "considerable".

Nowadays, the ecological condition of the bottom sediments in Danube Lakes is assessed as "satisfactory", except in Kuhurlui, Yalpuh and Kitai Lakes where the expert assessment is "unsatisfactory".

The ecological risk level of the bottom deposit pollution in Danube Lakes is assessed from "high" $(54.5 \%)$ to "considerable" $(45.5 \%)$.

Presence of pollutants in water is rather occasional. Their concentration within a site in a spatial-temporal distribution can change considerably. From this viewpoint, the assessment of the bottom sediment pollution in the water basins and water flows ecosystems can be not only additional but also more representative.

When applying assessment measures for the determination of the risk of bottom sediment pollution in the water basins of the region, it should be taken into account that the bottom sediments present the accepting environment as well as the secondary source of pollutants that are found in the aquatic environment. The processes of erosion taking place due to the bed flow dynamics and wind-wave impact contribute to high risks that the secondary pollution processes in the water basins occur.

Recognition of the bottom deposits as a potential source of the secondary pollution of water should be accomplished with due account of the assessment of the long-time interaction between the polluted bottom soil and water within the system "solution - suspension - bottom sediment layer".

Conclusions. The main conclusions are presented below.

1. The determined integral index of the land condition $I_{z-s t}$ within the boundaries of the Danube region varies from 3.00 to 3.16 and meets the requirements of the $2^{\text {nd }}$ group of objects while the quality condition of lands is assessed as "unsatisfactory".

2 . The risks that the soil ecosystem resistance can be disturbed were determined in Artsiz, Kiliia and Tatarbunar districts of the Ukrainian Danube region and were found to be minimal $\left(P_{s}^{c}=0.20\right)$. For Izmail and Reni districts the risk of the soil ecosystem disturbance level that exceeds the criterion is assessed as "high" $\left(P_{s}^{c}=0.25\right)$.

3. The ecological condition of soils at the locations where UPPCs are stored meets, predominantly, the "medium" category requirements. The ecological risk level varies between "high" and "considerable" $\left(P_{s}^{c}=0.25-0.40\right)$. However, near the UPPC warehouses in Shevchenkove village of Kiliia district and in Zadunaivka village of Artsiz district the maximum levels of the environmental pollution were recorded. The general ecological condition of soils in the mentioned areas is assessed as "bad" and the ecological risk level is "high" $\left(P_{s}^{c}=0.60-0.65\right)$.

4. In the Danube sites near Izmail town and within the boundaries of Ochakiv estuary, Bystryi arm and Starostambylskyi estuary the values of bottom sediment pollution confirm "satisfactory" condition. Still, the ecological condition of bottom sediments within the boundaries of Reni town and Vylkovo town is assessed as "unsatisfactory". As of today, the ecological risk level of pollution for the entire Ukrainian section of the Danube is assessed by experts within the "high" - "considerable" range.

5. Nowadays the general ecological condition of bottom sediments in Danube Lakes is assessed as "satisfactory", except for Kuhgurlui, Yalpuh and Kitai Lakes where the ecological condition of bottom sediments is assessed as "unsatisfactory". The ecological risk of the bottom sediment pollution in Danube Lakes is assessed by experts within the "high" "considerable" range.

6. The residual quantity of the UPPC (DDT, DDE, DDD and $\gamma-\mathrm{HCCH} /$ lindane, geptachlorine) in the Danube bottom sediments (between Reni town and the estuary part of the river) and in Danube Lakes was not detected in the tested samples (within the laboratory method sensitivity limits).

7. It should be remarked that the promising direction of the future studies is to assess the ecological risk of the Danube water pollution and pollution of water basins and water flows of the Ukrainian section of the Danube region as well as to substantiate the connection between the soil condition and bottom sediments on one part and the pollution of the aquatic environment of the region on the other part.

\section{References.}

1. Melnyk, L.H., \& Kubatko, O.V. (2013). The efficiency of natural and resource potential using in Ukraine and preconditions of «green» economy forming. Socio-Economic Research Bulletin, 3(50), p. 2, 169-174.

2. Formation of ecological consciousness and raising awareness of stakeholders on the causes and pollution consequences of soil and water in Lower Danube Region (2016). Information materials within the project "Inventory, Assessment and Remediation of Anthropogenic Sources of Pollution in the Lower Danube Region of Ukraine, Romania and Republic of Moldova" (MIS ETC CODE 995). Odessa: FOP Shylov M.V.

3. SanPiN 42-128-4433-87. Sanitary standards for permissible concentrations of chemical substances in soil. (n.d.). Retrieved from https://zakon.rada.gov.ua/laws/show/ v4433400-87?lang=uk\# Text.

4. Dobrovolskiy, V. V. (2015). Basic principles of the environmental quality estimation theory. Scientific Works. Ecology, 244(256), 10-14

5. Burkynskyi, B. V., \& Khumarova, N. I. (2013). Institutional mechanism of ecological-oriented strategic plans for national economy development. Ecological Sciences, 3, 139-148.

6. Khvesyk, M. A., \& Stepanenko, A. V. (2014). Ecologic crisis in Ukraine: social and economic consequences and the ways of its overcoming. Economy of Ukraine, 1, 74-86.

7. Ivaniuta, S. P., \& Kachynskyi, A. B. (2013). The ecological security of the regions of Ukraine: comparative estimation. Strategic Priorities, 33(28), 157-164.

8. Shaporenko, O.I. (2014). Economic and Environmental Risks: Definition, Assessment, Management and Principles. Vcheni zapysky Universytetu “KROK”, 35, 182-189. 
9. Kozulia, T. V., \& Emelyanova, D. I. (2015). Environmental risk at different levels of natural and industrial systems study, informational estimation support. Problems of Information Technologies, 1, 138-144.

10. Sornette, D., Maillart, T., \& Kröger, W. (2013). Exploring the limits of safety analysis in complex technological systems. International Journal of Disaster Risk Reduction, 6, 59-66. https://doi.org/10.1016/j.ijdrr.2013.04.002.

11. Tarazona, J.V., Versonnen, B., Janssen, C., De Laender, F., Vangheluwe, M., \& Knight, D. (Eds.) (2014). Principles for Environmental Risk Assessment of the Sediment Compartment: Proceedings of the Topical Scientific Workshop. Helsinki: European Chemicals Agency. Retrieved from https:/echa.europa.eu/documents/10162/22816050/environmental_risk_assessment_final_en.pdf/3515b6856601-40ce-bd48-3f8d5332c0f8.

12. Bschir, K. (2017). Risk, Uncertainty and Precaution in Science: The Threshold of the Toxicological Concern Approach in Food Toxicology. Science and Engineering Ethics, 23, 489-508. https://doi.org/10.1007/s11948-016-9773-2.

13. O'Brien, G. C., Dickens, C., Hines, E., Wepener, V., Stassen, R., Quayle, L., ..., \& Landis, W. G. (2018). A regionalscale ecological risk framework for environmental flow evaluations. Hydrology and Earth System Sciences, 22(2), 957-975. https://doi.org/10.5194/hess-22-957-2018.

14. Dutt, L.S., \& Kurian, M. (2013). Handling of Uncertainty - A Survey. International Journal of Scientific and Research Publications, 3(1), 1-4.

15. Grizzetti, B., Liquete, C., Antunes, P., Carvalho, L., Geamănă, N., Giucă, R., Leone, M., ..., \& Woods, H. (2016). Ecosystem services for water policy: Insights across Europe. Environmental Science \& Policy, 66, 179-190. https://doi. org/10.1016/j.envsci.2016.09.006.

16. Serbov, M. (2018). Methodological approaches in development of value estimation of costs of freshwater resources of the water basin by the objects of nature use. Technology Audit and Production Reserves, 1/5(39), 74-78. https://doi. org/10.15587/2312-8372.2018.124684.

17. Serbov, M.H., Hryb, O.M., \& Pylypiuk, V.V. (2019). Methodological approaches and results of assessment of ecological risks of soil and bottom sediment pollution of water bodies of the Ukrainian Danube. Rivers and Estuaries of the Black Sea at the Beginning of the XXI Century: Materials of the All-Ukrainian scientific-practical conference, 133-135. Retrieved from http:// odeku.edu.ua/wp-content/uploads/ Zbirnik_materialiv_konf_Richki-ta-limani-Pivnichno-Zahidnogo-Prichornomorya-na-pochatku-HHI-st.pdf.

18. Rybalova, O. V., \& Belan, S. V. (2013). Environmental risk of deterioration of soils and land resources of Ukraine. Ecology and industry, 3, 15-22.

19. Vasenko, O.H., Rybalova, O.V., Artemiev, S.R., Horban, N. S., Korobkova, G. V, Polozentsieva, V. O., ..., \& Savichiev, A.A. (2015). Integral and integrated assessments of the state of the environment. Kharkiv: National University of Civil Defence of Ukraine. Retrieved from http:// repositsc.nuczu. edu.ua/handle/123456789/6524.

20. DSanPiN 8.8.1.2.3.4.-00-2001. Permissible doses, concentrations, quantities and levels of pesticides in agricultural raw materials, foodstuffs, air of the working area, atmospheric air, water of reservoirs, soil (n.d.). Retrieved from https://zakon. rada.gov.ua/rada/show/v01375 88-01\#Text.

\section{Оцінка екологічного ризику забруднення грунтів і донних відкладень Українського Придунав'я}

\section{М. Г. Сербов, О. М. Гриб, В. В. Пилип'юк}

Одеський державний екологічний університет, м. Одеса, Україна, e-mail: serbovng@gmail.com
Мета. Оцінка екологічних ризиків забруднення грунтів на ділянках зберігання непридатних хімічних засобів захисту рослин і донних відкладень на українській ділянці річки Дунай та придунайських озерах.

Методика. Використані методи аналізу й синтезу даних моніторингу об'єктів дослідження, порівняльного зіставлення, логічного узагальнення та аналогій, у поєднанні з експертними оцінками, монографічними та графоаналітичними дослідженнями. Результати представлені на підставі проведених польових і лабораторних досліджень.

Результати. Визначено, що стан земельних ресурсів Придунайського регіону України $є$ «незадовільний». Ризик порушення стійкості екосистем грунтів для більшості території регіону оцінюється як «підвищений». Результати моніторингу у місцях зберігання непридатних хімічних засобів захисту рослин показують перевищення гранично допустимих концентрацій окремих забруднюючих речовин у 5,0-32,0 рази. Екологічний стан грунтів оцінюється як «посередній» - «важкий» із ризиками на рівні «значний» - «високий». Екологічний стан донних відкладень нижнього Дунаю оцінюється як «задовільний». У придунайських озерах стан донних відкладень $€$ «задовільний», за виключенням озер Кугурлуй, Ялпуг і Китай, де він «незадовільний». Рівень екологічного ризику для української ділянки річки Дунай і придунайських озер оцінюється в діапазоні «підвищений» - «значний».

Наукова новизна. Уперше для Придунайського регіону України проведена комплексна оцінка екологічного ризику забруднення грунтів, що включала в себе оцінку ризику порушення стійкості екосистеми грунтів та оцінку ризику при зберіганні непридатних хімічних засобів захисту рослин. Була здійснена комплексна оцінка забруднення донних відкладень на ділянці між містом Рені та гирлом Дунаю і у придунайських озерах. На основі аналізу існуючих методик оцінки екологічного ризику забруднення грунтів і донних відкладень розроблені й застосовані рекомендації щодо використання індикаторних показників екологічного стану з урахуванням критеріїв фізичної деградації та забруднення.

Практична значимість. Отримані результати можуть бути спрямовані на формування стратегії ефективного та сталого управління природними ресурсами Українського Придунав'я на основі інструментів і механізмів, націлених на вирішення проблем соціально-економічного розвитку з урахуванням імовірного впливу дестабілізуючих факторів.

Ключові слова: Українське Придунав'є, екологічний ризик, стан, забруднення, грунти, донні відкладення

\section{Оценка экологического риска загрязнения грунтов и донных отложений Украинского Придунавья}

\section{Н. Г. Сербов, О. Н. Гриб, В. В. Пилипюк}

Одесский государственный экологический университет, г. Одесса, Украина, e-mail: serbovng@gmail.com

Цель. Оценка экологических рисков загрязнения почв на участках хранения непригодных химических средств защиты растений и донных отложений на украинском участке реки Дунай и придунайских озерах.

Методика. Использованы методы анализа и синтеза данных мониторинга объектов исследования, сравнительного сопоставления, логического обобщения и аналогии, в сочетании с экспертными оценками, монографическими и графоаналитическими исследованиями. Результаты представлены на основании проведенных полевых и лабораторных исследований. 
Результаты. Определено, что состояние земельных ресурсов Придунайского региона Украины является «неудовлетворительным». Риск нарушения устойчивости экосистем почв для большей части территории региона оценивается как «повышенный». Результаты мониторинга в местах хранения непригодных химических средств защиты растений показывают превышение предельно допустимых концентраций отдельных загрязняющих веществ в 5,0-32,0 раза. Экологическое состояние почв оценивается как «посредственное» - «тяжелое» с рисками на уровне «значительный» - «высокий». Экологическое состояние донных отложений нижнего Дуная оценено как «удовлетворительное». В придунайских озерах состояние донных отложений «удовлетворительное», исключая озера Кугурлуй, Ялпуг и Китай, где оно «неудовлетворительное». Уровень экологического риска для украинского участка реки Дунай и придунайских озер оценивается в диапазоне «повышенный» - «значительный».

Научная новизна. Впервые для Придунайского региона Украины проведена комплексная оценка экологического риска загрязнения почв, которая включала в себя оценку риска нарушения устойчивости экосистемы почв и оценку риска при хранении непригодных химических средств защиты растений. Была осушествлена комплексная оценка загрязнения донных отложений на участке между городом Рени и устьем Дуная и в придунайских озерах. На основе анализа существующих методик оценки экологического риска загрязнения почв и донных отложений разработаны и применены рекомендации по использованию индикаторных показателей экологического состояния с учетом критериев физической деградации и загрязнения.

Практическая значимость. Полученные результаты могут быть направлены на формирование стратегии эффективного и устойчивого управления природными ресурсами Украинского Придунавья на основе инструментов и механизмов, нацеленных на решение проблем социально-экономического развития с учетом вероятного влияния дестабилизирующих факторов.

Ключевые слова: Украинское Придунавье, экологический риск, состояние, загрязнение, почвы, донные отложения

Recommended for publication by Yu.S. Tuchkovenko, Doctor of Geographical Sciences. The manuscript was submitted 26.10.20 